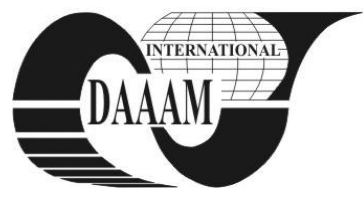

Annals of DAAAM for 2011 \& Proceedings of the 22nd International DAAAM Symposium, Volume 22, No. 1, ISSN 1726-9679 ISBN 978-3-901509-83-4, Editor B. Katalinic, Published by DAAAM International, Vienna, Austria, EU, 2011 Make Harmony between Technology and Nature, and Your Mind will Fly Free as a Bird Annals \& Proceedings of DAAAM International 2011

\title{
MONITORING OF RHEOLOGICAL PROPERTIES OF POLYPROPYLENE
}

\author{
VOJTKO, I[mrich] \& MIKITA, J[ozef]
}

\begin{abstract}
The article deals with the evaluation of the impact of the addition of recycled material in the pure material in the processing of thermoplastic injection molding technology.The experiment was determined what proportion of recycled material in the pure material is acceptable to secure the required rheological properties of processed material injection molding technology. To assess the rheological properties was used melt volume rate index MVR of thermoplastic materials. The experiment was conducted in specialized laboratory support equipment according to STN EN ISO 1133.
\end{abstract}

Key words: rheology, recycled material, polypropylene, plastic

\section{INTRODUCTION}

Rheology describes the deformation of a body under the influence of stresses. "Bodies" in this context can be solids, liquids, or gases. Ideal solids deform elastically. The energy required for the deformation is fully recovered when the stresses are removed. Ideal fluids such as liquids and gases deform irreversibly - they flow. The energy required for the deformation is dissipated within the fluid in the form of heat and cannot be recovered simply by removing the stresses.

Measurement of rheological properties of polymers is important for several reasons. Their knowledge helps us to formulate a polymeric system that would best meet the individual requirements of the physical properties of finished plastic products. This fact shows that the rheological properties directly affect the processing conditions, eg. injection temperature and pressure during extrusion.

\section{DESCRIPTION OF WORK METHODOLOGY, MATERIALS AND EXPERIMENTS}

Tested material was polypropylene Hostacom M2 N01 what is a $20 \%$ mineral filled PP homopolymer, with low flow, good stiffness. It is not intended for medical, pharmaceutical or drinking water applications. Melt volume-flow rate (MVR) was measured by Thermo Scientific HAAKE MeltFlow MT indexer. The test sample of $5 \mathrm{~g}$ was mixed from granulate and recycled polypropylene where the proportion of recycled material for each additional measurement increases by $5 \%$.

The area of the cylinder is inserted and secured on the underside of the capillary. After the stabilizing the temperature at the top and bottom of the cylinder measurement starts. A sample weighing $5 \mathrm{~g}$ is weighed on a digital weight METTLER TOLEDO PL-303 IC. With hopper sample is dropped into the cylinder cavity. After filling the sample is inserted piston without additional weight and gently pushed. The program is set preheat time of four minutes, during which the sample reaches the plastic state. After the sample is transformed into the plastic state program issues an instruction to load the piston weight $(5 \mathrm{~kg})$. The measurement starts by visiting the bottom of the reference marks of the reading device. Program notes, displayed in real time precisely the values which are stored and displayed after the measurement. Measurement stops scanned the top of the reference marks of the piston.

\section{EVALUATION OF THE MEASUREMENT}

Average MVR is calculated from the results of individual 6 measurements (Fig. 1).

\begin{tabular}{|c|c|c|c|}
\hline $\begin{array}{c}\text { No. of } \\
\text { measurement }\end{array}$ & $\begin{array}{c}\text { Percentage of } \\
\text { net } \\
\text { Polypropylene }\end{array}$ & $\begin{array}{c}\text { Percentage of } \\
\text { recycled } \\
\text { material }\end{array}$ & $\begin{array}{c}\text { Average value of } \\
\text { MVR }\end{array}$ \\
\hline 1 & $100 \%$ & $0 \%$ & $11,0676 \mathrm{~cm}^{3} / 10 \mathrm{~min}$ \\
\hline 2 & $95 \%$ & $5 \%$ & $11,4175 \mathrm{~cm}^{3} / 10 \mathrm{~min}$ \\
\hline 3 & $90 \%$ & $10 \%$ & $11,5429 \mathrm{~cm}^{3} / 10 \mathrm{~min}$ \\
\hline 4 & $85 \%$ & $15 \%$ & $11,8436 \mathrm{~cm}^{3} / 10 \mathrm{~min}$ \\
\hline 5 & $80 \%$ & $20 \%$ & $12,1334 \mathrm{~cm}^{3} / 10 \mathrm{~min}$ \\
\hline 6 & $75 \%$ & $25 \%$ & $12,2088 \mathrm{~cm}^{3} / 10 \mathrm{~min}$ \\
\hline 7 & $70 \%$ & $30 \%$ & $12,5307 \mathrm{~cm}^{3} / 10 \mathrm{~min}$ \\
\hline 8 & $65 \%$ & $35 \%$ & $12,9547 \mathrm{~cm}^{3} / 10 \mathrm{~min}$ \\
\hline 9 & $60 \%$ & $40 \%$ & $13,2110 \mathrm{~cm}^{3} / 10 \mathrm{~min}$ \\
\hline 10 & $55 \%$ & $45 \%$ & $13,2777 \mathrm{~cm}^{3} / 10 \mathrm{~min}$ \\
\hline 11 & $50 \%$ & $50 \%$ & $13,6323 \mathrm{~cm}^{3} / 10 \mathrm{~min}$ \\
\hline 12 & $45 \%$ & $55 \%$ & $13,9530 \mathrm{~cm}^{3} / 10 \mathrm{~min}$ \\
\hline 13 & $40 \%$ & $60 \%$ & $14,3784 \mathrm{~cm}^{3} / 10 \mathrm{~min}$ \\
\hline 14 & $35 \%$ & $65 \%$ & $14,3050 \mathrm{~cm}^{3} / 10 \mathrm{~min}$ \\
\hline 15 & $30 \%$ & $70 \%$ & $14,7167 \mathrm{~cm}^{3} / 10 \mathrm{~min}$ \\
\hline 16 & $25 \%$ & $75 \%$ & $15,0546 \mathrm{~cm}^{3} / 10 \mathrm{~min}$ \\
\hline 17 & $20 \%$ & $80 \%$ & $15,3162 \mathrm{~cm}^{3} / 10 \mathrm{~min}$ \\
\hline 18 & $15 \%$ & $85 \%$ & $15,6732 \mathrm{~cm}^{3} / 10 \mathrm{~min}$ \\
\hline 19 & $10 \%$ & $90 \%$ & $15,7689 \mathrm{~cm}^{3} / 10 \mathrm{~min}$ \\
\hline 20 & $5 \%$ & $95 \%$ & $16,2549 \mathrm{~cm}^{3} / 10 \mathrm{~min}$ \\
\hline 21 & $0 \%$ & $100 \%$ & $16,7929 \mathrm{~cm}^{3} / 10 \mathrm{~min}$ \\
\hline
\end{tabular}

Fig. 1. Table of MVR values obtained by measuring

From the results it is clear that a gradual increase in representation of recycled material in the sample also increases the value of melt volume-flow rate. Since the material has a value of MVR sheet of material bounded by the values of 7-13 $\mathrm{cm}^{3} / 10$ min recycled material can add up to a maximum $35 \%$ share in the material. After crossing the $35 \%$ value share of recycled MVR value is above the range of material form and it can affect change in the quality of the product. Some correction process of processing parameters may be modified final product quality. Opaque mixture of recycled material and granulate may be non-homogeneous material (different fluidity) and the injection process may arise cold joints. Standard deviation from the average (mean) of all measurements has the value 1.6815 $\mathrm{cm}^{3} / 10 \mathrm{~min}$, and the average measured value is $1.6986 \mathrm{~cm}^{3} / 10$ $\min$.

Figure 2 shows the time of measurement with respect to individual measurements. Shortening the time trials in the difference between the first and the last measurement is 
approximately 50 seconds. Shortening the time would help reduce the time of injection and thus shorten the period of filling mold cavity. Acceptable value of adding recycled material is $65 \%$ granules to $35 \%$ of recycled material.

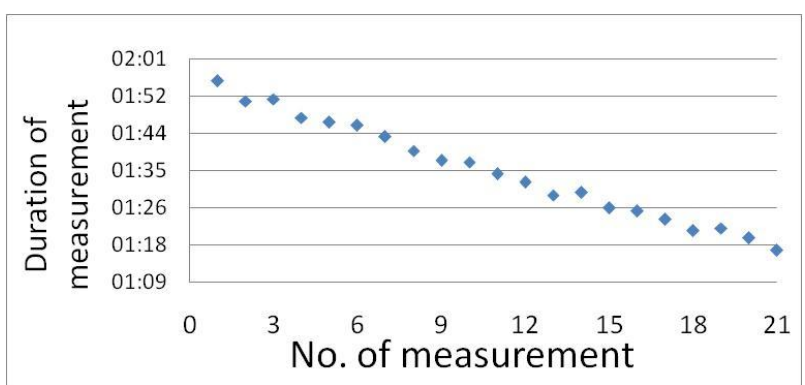

Fig. 2. The average measurement time in each measurement

As we can see on Figure 3 with the increasing amount of recycled material viscosity decreases rapidly.

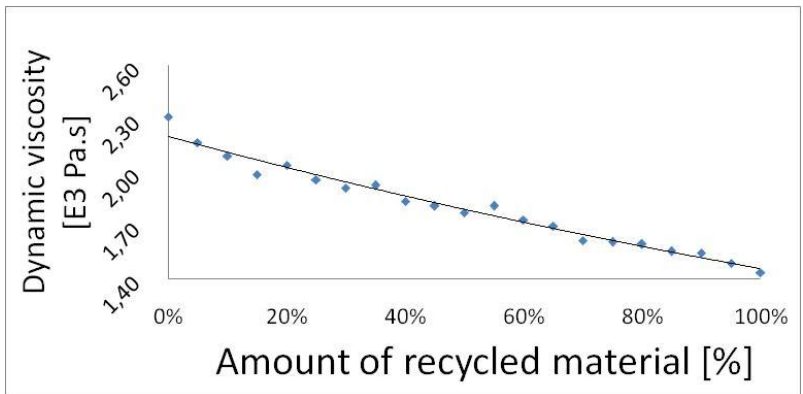

Fig. 3. Dependence of dynamic viscosity on the addition of recycled material

With the increasing of melt volume-flow index, according to the chart in Fig. 4 value of viscosity decreased [ $\eta]$. Lower viscosity can cause rejects and overflow. The low value of viscosity can occur in some places the product burns. This product defects can be removed using a small proportion of granules and recycled, thereby reducing the melt flow index. Otherwise, if the value is too high viscosity may give rise to incomplete products; this means that the low melt flow index did not fill the whole mold cavity. The high viscosity may also give rise to depression, withdrawal and ripple the surface location.

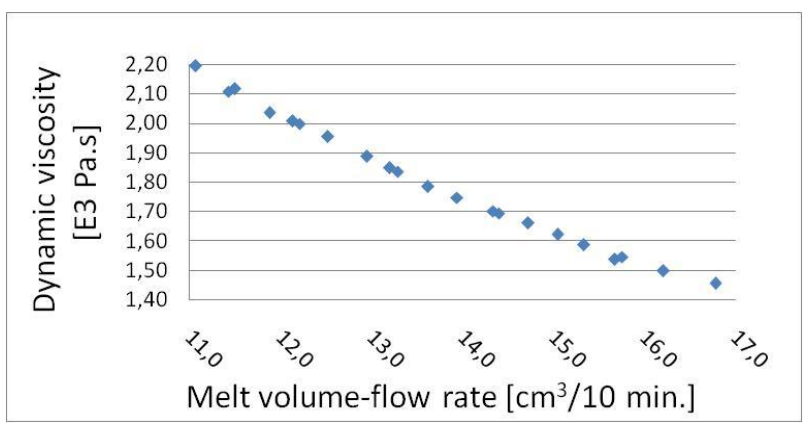

Fig. 4. Dependence of dynamic viscosity and MVR

The shear stress $\tau$ causes the liquid to flow in a special pattern. A maximum flow speed $v_{\max }$ is found at the upper boundary. The speed drops across the gap size y down to $\mathrm{v}_{\min }=$ 0 at the lower boundary contacting the stationary plate. Laminar flow means that infinitesimally thin liquid layers slide on top of each other, similar to the cards in a deck of cards. One laminar layer is then displaced with respect to the adjacent ones by a fraction of the total displacement encountered in the liquid between both plates.

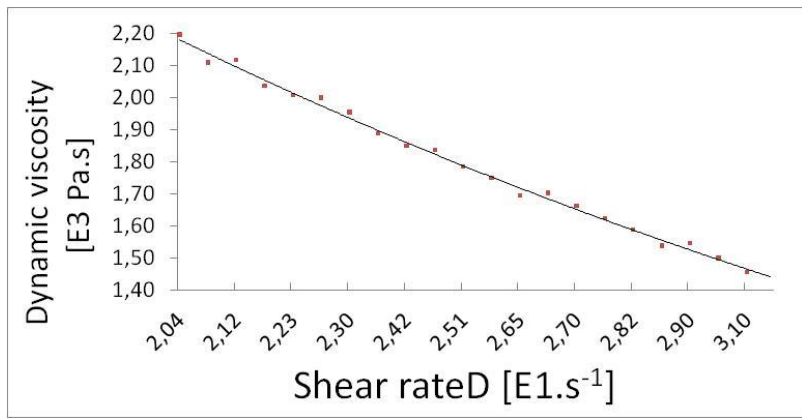

Fig. 5. Dependence of dynamic viscosity on shear rate

The chart shows that increasing the shear rate there is a reduction of viscosity. The cause of decline in viscosity, more or less developed macromolecules move easier. By reducing the temperature the melt viscosity increases. In practice, this means that the higher the value of the melt flow index, melt better then flows to all parts of the mold, especially in smaller and narrower parts.

\section{CONCLUSION}

As we can see on the charts of the different dependencies the addition of recycled material greatly influenced different material properties. All of these material properties are an important indicator in the processing of plastics injection molding technology. Based on determination of the addition of recycled material in pure material and its impact on the MVR we can say that the maximum limit of added recycled material is 30 to $35 \%$. This article originated as a result of the cooperation of our department and company dealing in plastics processing technology.

\section{ACKNOWLEDGEMENTS}

This contribution has been supported by research grant KEGA 3/7167/09 (Proposal of interactive educational manual for the area of computer systems support the technological preparation of production).

\section{REFERENCES}

Baron, P.; Kočiško, M.; Janák, M.: Verification and optimization of work productivity at technological line for processing of worn tyres to rubbery grit, Proceedings of ICCMS, ISBN 978-1-4244-9241-1, pp. 32-36, IEEE, Mumbai, India

Brožek, M.; Müller, M.: Mechanické vlastnosti spojů lepených sekundovými lepidly, Strojírenská technologie, 9, 1, (2004), 9-15, ISSN 1211-4162

Dobránsky, J. et al.: Simulácia zatekania termoplastu pri výrobe výrobku pre automobilový priemysel pomocou technonológie vstrekovania plastov. Plasty a kaučuk. 46, 910, (2009), 271-274, ISSN 0322-7340

Panda, A. et al.: Optimalizácia tepelného spracovania ložiskových krúžkov s ciel’om eliminovat' deformácie materiálu, Chemické listy, 105, S, (2011), 459-461, ISSN 0009-2770

Ragan, E.; Baron, P; Dobránsky, J.: Sucking machinery of transport for dosing granulations of plastics at injection molding, Proceedings of ICMST, ISBN 978-1-4244-87585, pp. 133-136, IEEE, Kuala Lumpur, Malaysia

Svetlík, J.; Demeč, P.: Virtual machining and its experimental verification, Acta Mechanica Slovaca, 13, 4, (2009), 68-73, ISSN 1335-2393

Šebo, J.; Svetlík, J.: Návrh a ekonomické zhodnotenie automatizovaného demontážneho pracoviska, Transfer inovácií, 18, (2010), 99-102, ISSN 1337-7094 